Regional Review

\title{
Spatial analysis and identification of high risk plague regions in Pakistan based on associated rodent species distribution
}

\author{
Madiha Shabbir ${ }^{1}$, Maha Aleem ${ }^{1}$, Sundus Javed ${ }^{1}$, David M Wagner², Paul S Keim², Syed Ali Musstjab \\ Akbar Shah Eqani ${ }^{1}$, Habib Bokhari ${ }^{1}$ \\ ${ }^{1}$ Department of Biosciences, COMSATS Institute of Information Technology, Islamabad, Pakistan \\ ${ }^{2}$ Center for Microbial Genetics and Genomics and Department of Biological Sciences, Northern Arizona University, \\ Flagstaff, AZ, United States
}

\begin{abstract}
Plague, caused by Yersinia pestitis, is an infectious bacterial disease that has a high fatality rate if untreated. Rodents are plague reservoirs and play an important role in disease spread. Plague cases have been reported extensively since the second pandemic from the 14th century in countries sharing borders with Pakistan, such as China and India, as well as nearby countries including Russia and central Asia. Despite being centrally located in a plague-infested geographical zone, there has been no plague incidence reported from Pakistan. This study aims to pinpoint some of the potentially important aspects of the disease, which have to be considered when assessing potential risk associated with a plague outbreak in Pakistan. In this context, the occurrence and distribution of plague-associated rodent reservoirs in different regions of Pakistan in relation to those found in the neighboring countries were mapped. In addition, the climatic factors that may also influence disease spread by affecting the growth of the bacteria are also discussed. The combined epidemiological and ecological surveillance studies suggest a prevalence of several potential rodent carriers in certain districts with the possibility of a plague outbreak in Pakistan.
\end{abstract}

Key words: Pakistan; plague; pandemic; rodents; prevalence, Yersinia pestis.

J Infect Dev Ctries 2016; 10(7):687-693. doi:10.3855/jidc.7091

(Received 04 May 2015 - Accepted 20 October 2015)

Copyright $(C) 2016$ Shabbir et al. This is an open-access article distributed under the Creative Commons Attribution License, which permits unrestricted use, distribution, and reproduction in any medium, provided the original work is properly cited.

\section{Introduction}

Plague is a severe infectious disease caused by the bacterium Yersinia pestis. This disease has been associated with human pandemics since the 6th century and has caused tens of millions of deaths worldwide [1]. The plague epidemic during the years 1347-1351 is commonly referred to as the "Black Death" and is thought to have originated in the arid regions of central Asia, transmitted via black rats [2]. The history of plague in central Asia is quite extensive. In spite of constant threat of the disease since several years, the situation is not well regulated in some countries bordering Pakistan. Considering the proximity of these plague foci to Pakistan, it is surprising that no case has ever been reported from the country. In this study, we aimed to investigate and highlight plague risk in Pakistan, which may have gone unreported or been misdiagnosed due to lack of awareness or resources. Therefore, plague hosts and climatic conditions were taken under consideration, especially those that are common between the affected neighboring countries and Pakistan. Rodents act as major reservoirs of $Y$. pestis, transmitting the disease to humans and other mammals [3]. The disease is transmitted from host to host by fleas via blood feeding, consumption or handling of infectious tissue, or through inhalation of infectious materials [4]. Rodents are key factors, being the predominant hosts of $Y$. pestis. Consequently, in order to study the prevalence of plague in any region, it is important to consider plague reservoirs along with the climatic conditions, which may affect the spread of plague.

\section{Plague pandemics in the Asian continent}

Plague probably originated in central Asia and began spreading westward along major trade routes, such as the Silk Road and Tea-Horse Road [5]. Plague cases have been reported extensively since the second pandemic in countries neighboring Pakistan such as China, Russia, India, Iran, and Afghanistan. In China and India, the fatality rate due to plague during 19942003 was 7\% [6]. Major foci of the bacterium were found in Xinjiang, Yunnan, Qinghai, and in Tibet of China [7]. Similarly, after the 14th century, plague 
affected a major part of India. During 1889-1950, India experienced almost 12.5 million deaths [8]. Recently, in 2004, Y. pestis was isolated from Rattus rattus and Mus musculus in Uttaranchal, India, which borders Tibet, China [9]. The Punjab region of India historically had also shown plague prevalence [10]. During the past 400 years, Iran experienced several human plague outbreaks; hence, plague has been the most-recorded epidemic between 1794 and 1925 and then again in the 20th century. Furthermore, on the eastern border of Iran, plague broke out during 1829-1833 in the province Khorasan, and then again in 1877 [11]. The first reported epidemic of plague in Afghanistan occurred in the 11th century in the city of Ghazni. Meanwhile, Kandahar and Sheikhdzhum also suffered from the disease during the 12th century. The last suspected plague epidemics in Afghanistan were in 1905, extending from Kabul to the Gelmand Valley, and in Kusan and Badghis in 1912 [12,13]. Natural plague foci have occurred over $28.3 \%$ of Mongolia, and it has been reported that $47.1 \%$ of these foci remain highly active, with human cases reported since 1897 [14]. Despite being in the middle of this plague-affected region, no outbreaks have been reported so far from Pakistan. Since this lack in notification of plague cases could also be due to lack in public awareness or inappropriate surveillance regarding the disease, we decided to look at prevalence of plague host reserviors in the region to determine potential risk.

\section{Rodent reservoirs in the Asian continent}

Currently, the disease circulates between rodent populations all over the world. The great gerbil $(R$. opimus) was considered the most important host in the central Asian desert, and plague has been known to spread extensively in southwestern China [3,15]. There are some plague reservoirs in China that have posed a significant risk to human life in the past two hundred years such as Marmota himalayana, Marmota bobak, Rattus villosissimus, Spermophilus dauricus, Lasiopodomys brandtii, Eothenomys miletus, and other field mice [16]. The dominant hosts in Yunnan province are Rattus flavipectus, Apodemus chevrieri, and Rattus norvegicus [17]. The presence of host species for plague such as Meriones hurrianae and Tatera indica in India has also been reported previously [18]. Meriones libycus followed by Hemiechinus auritis have been the main host reservoirs in the areas of Khorasan, Iran [19]. Keeping in mind this extensive presence of the disease in the Asian continent, it seems surprising that no cases of plague have been reported so far from Pakistan. Since maintaining a constant surveillance system in a country like Pakistan for diseases that have not been emerging is not a priority, it is difficult to comment on the complete absence of plague in the region. The lack of plague reports from Pakistan could also reflect the fact that the cases have either been misdiagnosed or gone unreported.

In order to analyze the risk of plague in Pakistan, the presence of specific host rodent species relevant to plague, especially in the neighboring countries of Pakistan, were identified. This was accomplished by a thorough literature search using keywords carrier rodent species in Pakistan, with data from 1935 up to 2014 using Google Scholar. In order to verify the presence of these host reservoirs in Pakistan, the literature search was limited to only those districts where data of host species was available.

According to previous studies, the most important hosts of plague in the neighboring countries of Pakistan are Rhombomys opimus (great gerbil) [20], Marmota caudate (long-tailed marmots) [21], Acomys ahirinus (cairo spiny mouse), Alticola argentatus (silver mountain vole) and Ellobius fuscocapillus (southern mole vole) [22], Mus musculus [23], Bandicota bengalensis (lesser bandicoot rat) [24], and Rattus rattus [25]. Based on the existing knowledge, we searched these potential plague carrier rodent species in different districts of Pakistan.

This enabled us to determine a synchronized distribution of potential plague-carrier host rodents in particular parts or districts of Pakistan. The results are based on data explored from various reports in the 32 districts and the subsequent presence of various potential plague-carrier rodent species.

\section{The district-wise distribution of rodents in Pakistan \\ Rhombomys opimus \\ Rhombomys opimus (great gerbil) is prevalent in India [26], Afghanistan [12], and Khorasan, Iran [19]; subsequently, its presence is commonly reported in different districts of Baluchistan province that border Iran and Afghanistan, i.e., Chagai [27], Quetta, Jaffarabad, and Kharan of Pakistan [28].}

\section{Mus musculus}

M. musculus (house mouse) is present all over the world, including Iran and Afghanistan [13]. In Pakistan, its presence has been reported from Quetta [29], Abbotabad and D. I. Khan [30], Faisalabad [31], Jaffarabad [27], Rawalpindi [32], Lahore [33], Sialkot [34], Sargodha [30], Punjab, in southern Sindh, i.e., 
Karachi City, Shaheed Benazirabad, Sukkur, and Hyderabad [35].

\section{Acomys ahirinus}

A. ahirinus (cairo spiny mouse) has been reported in Chagai [28]. Meanwhile, this species is also present in Dadu [36], Karachi, and Larkana, Sindh Pakistan [37].

\section{Bandicota bengalensis}

A. bengalensis (lesser bandicoot rat) is present in several districts in Bahawalpur [38], Swat, Swabi, Sukkur, Attock, Malakand of Punjab. In Quetta and D. I. Khan of Baluchistan, it also appears as one of the most prominent rodent species in the region [39].

\section{Ellobius fuscocapillus}

Ellobius fuscocapillus (southern mole vole) has been reported from Quetta, Baluchistan [40].

\section{Gerbillus gleadowi}

G. gleadow (hair-footed gerbil) has been reported in India [18]. In Pakistan, it has been found in Karachi, Shaheed Benazirabad, and Hyderabad districts, Sindh [41].

\section{Alticola argentatus}

A. argentatus (silver mountain vole) has been reported from the mountainous areas of central Asia, nNorthern Afghanistan, northwest frontier province (Khyber Pakhtunkhwa) in Pakistan, and Jammu and Kashmir. In Pakistan, this species has been reported from Mansehra, Muzaffarab, and Bagh and Dadu of the Khyber Pakhtunkhwa [36,42].

\section{Marmota caudate}

M. caudate (long-tailed marmot) tends to live in mountainous areas of Pakistan, e.g., Astore and Gilgit [43]. The district-wise distribution in our study depicts a high proportion of potential plague rodent carriers in Baluchistan (Figure 1). The data reflects the presence of plague-associated rodent species in districts bordering Iran and Afghanistan in the west, India in the east, and a few northern areas close to China.

Since several potential plague rodent species prevail in the country, we also examined whether the climatic conditions prevalent in Pakistan favored disease dispersal.

\section{Effect of climatic factors on infection}

Transmission of vector-borne infectious diseases is greatly affected by weather and climatic factors [44].
Figure 1. Map showing number of plague-associated rodent species in studied districts of Pakistan in comparison with neighboring countries.

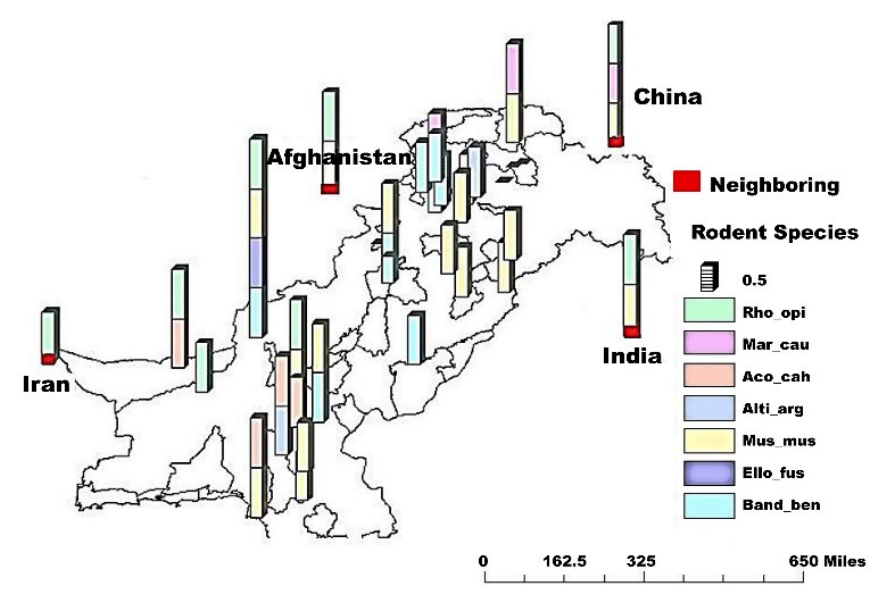

Change in climate has an important impact on the dispersion and abundance of pathogens as well as their respective zoonotic vectors in the environment [45].

Fluctuation in rodents and associated flea populations can occur due to temperature, rainfall, and relative humidity, with warm moist weather resulting in the availability of more hosts for the growth of bacteria, which may increase the transmission rates of plague [26].

In central Asia, where human plague is still reported regularly, field data from 1949-1995 show that $Y$. pestis prevalence in $R$. opimus increases with warmer springs and wetter summers. A study based on data from natural plague foci of Kazakhstan shows that a $1^{\circ} \mathrm{C}$ increase in spring is predicted to lead to a $>50 \%$ increase in the prevalence of plague [46]. Countries in central Asia show extreme temperatures, which is similar to most of the districts in Pakistan, where potential plaguecarrying rodents prevail. Similarly, in the 1900s, it was suggested that seasonal variations in temperature and humidity are responsible for the seasonal patterns of human plague incidence in India [26]; therefore, the relationship between climate and plague could be useful in predicting periods of increased risk of plague transmission.

Since Pakistan shares common key climatic variables of the disease spread (including temperature, humidity, and precipitation) with neighboring countries, most of the indicators for the prevalence and spread of the disease could be predicted to follow a similar pattern. For this purpose, we acquired data on climatic factors from the National Meteorology Department of Islamabad, Pakistan (Figure 2). These findings further magnify the importance of studying 
prevalence of plague in Pakistan. Furthermore, we decided to explore the potential host rodent species existing in different districts of Pakistan. In order to accomplish this, a novel geographic information system (GIS)-based mapping on plague carrying rodent species in Pakistan was developed using ArcGIS to highlight the potential risk factors that are involved in the spread of plague in Pakistan (Figure 1).

Climate change is the most important global concern, and Pakistan has been one of the badly affected countries, with temperature fluctuation and floods in recent years throughout the region. With the rapidly changing environmental conditions, especially temperature and rainfall, it is important to understand the impacts of glacial meltdown on flood dynamics and associated disease spread. As we discussed earlier, some neighboring countries of Pakistan have shown the presence of plague. Interestingly, Pakistan shares many of the potential plague-carrying rodent species with its neighboring countries. Our results highlight the fact that most of the studied districts show favorable climatic conditions for spread of plague, such as high temperatures, among others (Figure 2).

Moreover, natural disasters such as floods have affected these areas over the decades repeatedly, which may lead to a possibility of increased migration of rodents carrying the disease across borders of floodaffected regions [47]. Indeed, displacement of some rodent species as a result of flooding has been previously reported for Rattus rattus [47]. However, further studies are required to establish the validity of this hypothesis for most plague-carrying rodents. Recent flooding of northeastern India in June 2012 was reported [48]. Iran and Afghanistan were also struck by floods in April 2012 [49], as was China in July 2012 [50]. In Pakistan, a series of devastating floods affected extensive areas in September 2012 [47] [51] in addition to the 2013 flood episode. Due to the shift in climate and heavy rainfall, flooding of major metropolitan cities of Pakistan, including Karachi and Lahore, resulted in the flooding of associated "Nalas" and underground seweage systems, which are the breeding places of rodents such as $R$. norvegicus [52]. Since the climatic conditions and spread of plague are well established, the factors involved in reported cases from neighboring countries favoring the spread of disease were also evaluated. Different studies cited in the literature reveal that rodent (including potential plague carriers) and plague spread can be associated with increasing temperatures [46]. In Pakistan between March and August, the temperature remains relatively high and gradually reaches an average of $31^{\circ} \mathrm{C}$ in June; this
Figure 2. Mean annual temperature of different districts of Pakistan and bordering provinces of neighboring countries with reported plague.

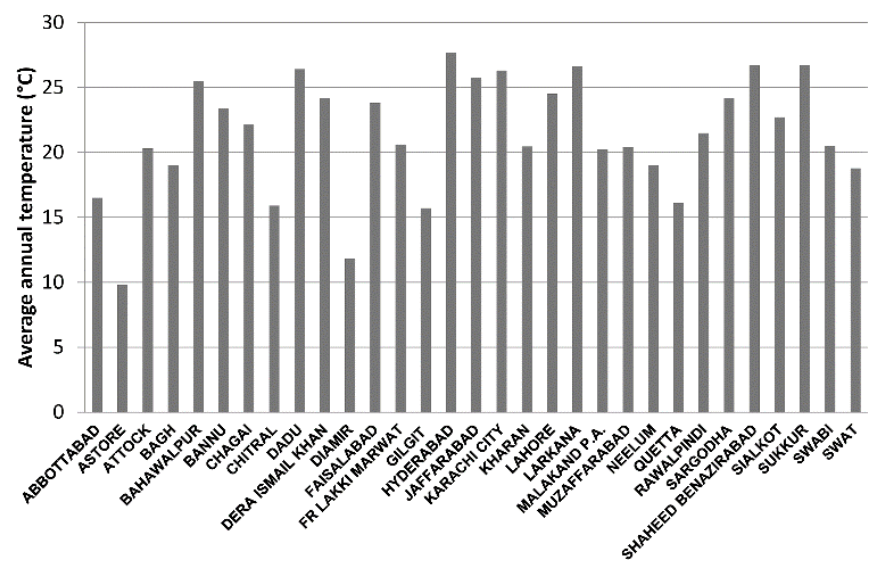

temperature is favorable for the spread of plague previously described for certain central Asian countries [46] (Figure 2).

In such climatic conditions, the possibility of plague incidence in Pakistan, especially in heavily populated districts, is high. Moreover, understanding the dynamics and behavior of different types of rodents is significant. Having these climatic conditions and an abundance of plague-carrier rodent species, it is imperative to evaluate the incidence of human plague in these districts. Such an understanding of the linkages between climatic and ecological changes and their use as determinants of disease re-emergence and distribution can ultimately contribute to timely identification of high-risk regions as well as optimization of appropriate preventive measures.

\section{Mapping plague transmission in Pakistan}

Major outbreaks of plague have been reported along the Pakistani border regions, i.e., in Tibet of China, which also borders Uttaranchal of India, as well as the Kashmir region of Pakistan. Similarly, Punjab of India, where cases have been reported, also borders Punjab of Pakistan [9]. Despite a lack of information about the disease in Pakistan, these bordering regions may provide useful information regarding the route for disease dispersal in the country. Also, one cannot deny the prevalence of plague in Pakistan despite the absence of reported cases because of Pakistan's proximity to neighboring regions with reported outbreaks as well as favorable climatic conditions for disease dispersal. 


\section{High plague risk zones}

As the regions in Iran bordering Pakistan have reported plague presence, there seems to be a higher risk of plague in southwestern areas of Pakistan, part of which are also bordered by Afghanistan. Khyber Pakhtunkhwa and northern areas bordering China describe fewer reports of host rodents, mainly because of less focus on research and subsequent unavailability of data from these regions. Predicting the possibility of plague occurrence in these areas is therefore uncertain. Districts of Punjab such as Lahore and Bahawalpur, which border Indian Punjab, also indicate the presence of rodent carrier species as discussed earlier [33].

M. musculus is the most prevalent rodent species in Pakistan, present in a majority of the districts [27,29$35]$. It is known to be involved in a few outbreaks of plague and serves as host to the disease in countries including Australia [53], India [10], and China [53]. Our survey shows that $R$. opimus and A. argentatus, potential hosts of $Y$. pestis, are commonly found in Pakistan and its neighboring countries India, China, and Iran. Similarly, M. caudata was found to be the main host in plague foci of Xinjiang, China [54], in central Asia, and in the former Soviet Union [55]; it is also prevalent in Pakistan, particularly in the Astore and Gilgit districts that border China. This further strengthens our observation that Pakistan has various rodent species in common with countries with reported outbreaks of plague. Taken together, these are strong indicators that it is highly imperative to further investigate disease foci in high-risk regions of Pakistan in order to determine the potential of plague incidence.

In Pakistan, due to a lack of quality surveillance programs, trained health practitioners, and awareness, plague may not be carefully monitored and reported. It is entirely possible that due to a lack of proper medical facilities in flood-affected regions and poor diagnostic potential of pneumonic and septicemic plague, we are turning a blind eye to a potential major public health threat. Therefore, in this review, we evaluated the possibilities in terms of the occurrence and spread of the disease, keeping in mind the geographic location of Pakistan with reference to its neighboring countries reporting active plague foci.

\section{Conclusions}

In the current study, we evaluated the favorability of overall climate of Pakistan and climate in particular regions of Pakistan for the growth and spread of plague. Our results are in congruence with published data from neighboring countries. We believe that monitoring the movement of the rodent population in Pakistan, even across the border, is of high importance in order to control the disease in case of any incidence. Furthermore, with the rapidly changing climate, efficient reporting systems, surveillance programs, and geographical information systems for plague should be established to avoid disease outbreaks.

\section{References}

1. Harbeck M, Seifert L, Hänsch S, Wagner DM, Birdsell D, Parise KL, Wiechmann I, Grupe G, Thomas A, Keim P, Zöller L, Bramanti B, Riehm JM, Scholz HC (2013) Yersinia pestis DNA from skeletal remains from the 6th century AD reveals insights into Justinianic Plague. PLoS Pathog 9: e1003349.

2. Alchon SA (2003) A pest in the land: new world epidemics in a global perspective, 1st edition. Albuquerque: University of New Mexico Press: 224 p

3. Gage KL, Kosoy MY (2005) Natural history of plague: perspectives from more than a century of research. Annu Rev Entomol 50: 505-528.

4. Zietz BP, Dunkelberg H (2004) The history of the plague and the research on the causative agent Yersinia pestis. Int J Hyg Environ Health 207: 165-178.

5. Cui Y, Yu C, Yan Y, Li D, Li Y, Jombart T, Weinert LA, Wang Z, Guo Z, Xu L, Zhang Y, Zheng H, Qin N, Xiao X, Wu M, Wang X, Zhou D, Qi Z, Du Z, Wu H, Yang X, Cao H, Wang H, Wang J, Yao S, Rakin A, Li Y, Falush D, Balloux F, Achtman M, Song Y, Wang J, Yang R (2013) Historical variations in mutation rate in an epidemic pathogen, Yersinia pestis. Proc Natl Acad Sci USA 110: 577-582.

6. Butler T (2009) Plague into the 21st century. Clin Infect Dis 49: 736-742.

7. Achtman M, Morelli G, Zhu P, Wirth T, Diehl I, Kusecek B, Vogler AJ, Wagner DM, Allender CJ, Easterday WR, ChenalFrancisque V, Worsham P, Thomson NR, Parkhill J, Lindler LE, Carniel E, Keim P (2004) Microevolution and history of the plague bacillus, Yersinia pestis. Proc Natl Acad Sci USA 101: 17837-17842.

8. Dennis D (1994) Plague in India. BMJ 309: 893-894.

9. Yu HL, Christakos G (2006) Spatiotemporal modelling and mapping of the bubonic plague epidemic in India. Int J Health Geogr 5: 12.

10. Mittal V, Rana U, Jain S, Kumar K, Pal I, Arya R, Ichhpujani RL, Lal S, Agarwal SP (2004) Quick control of bubonic plague outbreak in Uttar Kashi, India. J Commun Dis 36: 233-239.

11. Azizi MH, Azizi F (2010) A history of the human plague in Iran. Arch Iran Med 13: 563-569.

12. Zhang Y, Dai X, Wang X, Maituohuti A, Cui Y, Rehemu A, Wang Q, Meng W, Luo T, Guo R, Li B, Abudurexiti A, Song Y, Yang R, Cao H (2012) Dynamics of Yersinia pestis and its antibody response in great gerbils (Rhombomys opimus) by subcutaneous infection. PLoS One 7: e46820.

13. Shabani M, Darvish J (2013) Contemporary and sub-fossil house mice (Mus musculus Linnaeus, 1758) (Rodentia: Muridae) from Iran. Iran J Anim Biosys 6: 45-54.

14. Galdan B, Baatar U, Molotov B, Dashdavaa O (2010) Plague in Mongolia. Vector Borne Zoonotic Dis 10: 69-75.

15. Wilschut LI, Addink EA, Heesterbeek H, Heier L, Laudisoit A, Begon M, Davis S, Dubyanskiy VM, Burdelov LA, de Jong SM (2013) Potential corridors and barriers for plague spread in central Asia. Int J Health Geogr 12: 49. 
16. Benedict CA (1996) Bubonic plague in nineteenth-century China. Stanford: Stanford University Press, p: 256.

17. Luo LP, Guo XG, Qian TJ, Wu D, Men XY, Dong WG (2007) Distribution of gamasid mites on small mammals in Yunnan Province, China. Insect Sci 14: 71-78.

18. Parshad V (1999) Rodent control in India. Int J Pest Manage Rev 4: 97-126.

19. Wilschut L, Addink EA, Heesterbeek J, Dubyanskiy V, Davis S, Laudisoit A, Begon M, Burdelov LA, Atshabar BB, de Jong SM (2013) Mapping the distribution of the main host for plague in a complex landscape in Kazakhstan: an object-based approach using SPOT-5 XS, landsat 7 ETM+, SRTM and multiple random forests. Int J Appl Earth Obs 23: 81-94.

20. Davis S, Begon M, De Bruyn L, Ageyev VS, Klassovskiy NL, Pole SB, Viljugrein H, Stenseth NC, Leirs H (2004) Predictive thresholds for plague in Kazakhstan. Science 304: 736-738.

21. Chen Y, Wang Z, Zhang G, Fan W, Tao Y, He X, Zhao S (2012) Genetic characterization of four wild species of Chinese marmots using microsatellite markers. Biologia 67: 10131017.

22. Wang Y, Liu Q, Cong X, Xu C, Li Y (2007) Plague reservoirs and their classification in natural foci of China. Chinese $\mathrm{J}$ Vector Biol Control 18: 127-133.

23. Pocock M, Searle J, Betts W, White P (2001) Patterns of infection by Salmonella and Yersinia spp. in commensal house mouse (Mus musculus domesticus) populations. J Appl Microbiol 90: 755-760.

24. Pham HV, Dang DT, Minh NNT, Nguyen ND, Nguyen TV (2009) Correlates of environmental factors and human plague: an ecological study in Vietnam. Int J Epidemiol 38: 1634-1641.

25. Tollenaere C, Rahalison L, Ranjalahy M, Duplantier JM, Rahelinirina S, Telfer S, Brouat C (2010) Susceptibility to Yersinia pestis experimental infection in wild Rattus rattus, reservoir of plague in Madagascar. EcoHealth 7: 242-247.

26. Ari TB, Neerinckx S, Gage KL, Kreppel K, Laudisoit A, Leirs H, Stenseth NC (2011) Plague and climate: scales matter. PLoS Pathog 7: e1002160.

27. Rafiq M, Asif M (2008) Record of great gerbil, Rhombomys opimus, from Naukundi, Balochistan with comments on extension of its distribution range in Pakistan. Pak J Zool p. 387-388.

28. Ghalib SA, Jabbar A, Khan AR, Zehra A (2007) Current status of the mammals of Balochistan. Pak J Zool 39: 117.

29. Kakarsulemankhel JK (2004) "Kaal Daana" (Cutaneous Leishmaniasis) in South-West Pakistan: A Preliminary Study. Türkiye Parazitoloji Dergisi 28: 5-11.

30. Mushtaq M, Hussain I, Mian A, Munir S, Ahmed I, Khan AA (2013) Field evaluation of some bait additives against Indian crested porcupine (Hystrix indica) (Rodentia: Hystricidae). Integr Zool 8: 285-292.

31. Rafique A, Rana S, Khan H, Sohail A (2009) Prevalence of some helminths in rodents captured from different city structures including poultry farms and human population of Faisalabad, Pakistan. Pak Vet J 29: 141-144.

32. Mehmood A, Ansari M, Akhter S, Khan A, Hussain I, Qureshi T, Rakha BA (2012) Occurrence of pathogenic bacteria in small mammals-inhabiting poultry farms of Rawalpindi/Islamabad, Pakistan. Pak J Zool 44: 1185-1187.

33. Ahmad M, Maqbool A, Mahmood-ul-Hassan M, Mushtaq-ulHassan M, Anjum A (2011) Capillaria hepatica (Nematode) in rodents of the Lahore Metropolis Corporation-Pakistan. J Anim Plant Sci 21: 787-793.
34. Setzer WH (2011) Smithsonian Institution. Mus musculus domesticus. Available http://collections.si.edu/search/results.htm?q=record_ID:nmn hvz 7178339. Accessed: 12 June 2015.

35. Ab Ali R, Mahdi SF, Khan MF (2003) Estimation of Rodent Damage on Coconut Plantations and Sugarcane in Sindh. Pak J Biol Sci 12: 1051-1053.

36. Panhwar (1990) On uniqueness of Dadu District Sindh. J Sindhological Studies 2: 23, 32.

37. Khan MZ, Zehra A, Ghalib SA, Siddiqui S, Hussain B (2010) Vertebrate biodiversity and key mammalian species status of Hingol National Park. C J Pure Appl Sci 4: 1151-1162.

38. Sheikh, KM. Molur S (2004) Status and red list of pakistan's mammals. In Based on the conservation assessment and management plan workshop. Karachi: IUCN Pakistan. 20312p.

39. Pervez A, Ahmed SM, Khan AA, Lathiya SB (2005) Comparative field efficacy of some additive formulated baits against rodent pests of wheat crop in Sindh, Pakistan. Pak J Zool 37: 269.

40. Gharakheloo MM, Kivanç E (2003) A study on the morphology, karyology and distribution of Ellobius Fisher, 1814 (Mammalia: Rodentia) in Iran. Turk J Zool 27: 281-292.

41. International Union for Conservation of Nature and Natural Resources (2010) Gerbillus gleadowi. Available: http://www.iucnredlist.org/details/9124/0. Accessed: 10 June 2015.

42. Molur S (2008) Alticola argentatus. The IUCN red list of threatened species $2008 . \quad$ Available: http://dx.doi.org/10.2305/IUCN.UK.2008.RLTS.T949A13097 559.en Accessed: 10 June 2015.

43. Saffy H (2009) Long-tailed Marmot in Deosai National Park, Batlistan, Pakistan. ed2009.44. Collinge SK, Johnson WC, Ray C, Matchett R, Grensten J, Cully Jr JF, Gage KL, Kosoy M, Loye LE, Martin AP (2005) Testing the generality of a trophic-cascade model for plague. EcoHealth 2: 102-112.

45. Parmenter RR, Yadav EP, Parmenter CA, Ettestad P, Gage KL (1999) Incidence of plague associated with increased winterspring precipitation in New Mexico. Am J Trop Med Hyg 61: 814-821.

46. Stenseth NC, Samia NI, Viljugrein H, Kausrud KL, Begon M, Davis S, Leirs H, Dubyanskiy VM, Esper J, Ageyev VS, Klassovskiy NL, Pole SB, Chan KS (2006) Plague dynamics are driven by climate variation. Proc Natl Acad Sci USA 103: 13110-13115.

47. Wang ZW (1998) Rodent biology and management. International Conference on Rodent Biology and Management, Beijing, China.

48. Kasim A (2012) Pakistan, India hit by deadly flooding. CNN. Available:

http://www.cnn.com/2012/08/23/world/asia/pakistan-indiafloods. Accessed: 10 June 2015.

49. Eroshin A (2012) Earth Chnages and the Pole shift. Available: http://poleshift.ning.com/profiles/blogs/iran-afghanistansevere-floods-caused-enormous-damage-in-gilan-14. Accessed: 12 June 2015.

50. Whiteman H (2012) China doubles Beijing flood death toll. CNN Available: http://edition.cnn.com/2012/07/26/world/asia/china-beijingflood/index.html. Accessed: 12 June 2015.

51. CNN Wire Staff (2012) Hundreds killed in Pakistan flooding. CNN.

Available: 
http://edition.cnn.com/2012/09/29/world/asia/pakistanfloods/index.html. Accessed: 12 June 2015.

52. Channon D, Channon E, Roberts T, Haines R (2006) Hotspots: are some areas of sewer network prone to re-infestation by rats (Rattus norvegicus) year after year? Epidemiol and Infect 134: 41-48.

53. Yang H, Feng Z, Lu R, Zhang T, Liu M, Zhang S, et al. (2006) Study on Character of Plague Focuses in Guangdong Province. J Trop Med 6: 794-797.

54. Tong Z, Zhou D, Song Y, Zhang L, Pei D, Han Y, Hai M, Guang LQ, Lian L (2005) Pseudogene accumulation might promote the adaptive microevolution of Yersinia pestis. J Med Microbiol 54: 259-268.

55. Anisimov AP, Lindler LE, Pier GB (2004) Intraspecific diversity of Yersinia pestis. Clin Microbiol Rev 17: 434-464.

\section{Corresponding author}

Habib Bokhari, Professor

Department of Biosciences, COMSATS Institute of Information Technology,

Park Road, Chak shazad, Postal Code: 44000, Islamabad

Pakistan

Phone: +92 3005127684

Fax: +92-51-4442805.

Email: habib@comsats.edu.pk

Conflict of interests: No conflict of interests is declared. 